DOI https://doi.org/10.30525/978-9934-26-114-5-35

\title{
ВИКЛАДАННЯ ФІЛОСОФІЇ: СЕМІНАРУВАННЯ
}

\author{
Діденко Л. В. \\ кандидат філософських наук, дочент, \\ доичент кафедри філософії гуманітарних наук філософського \\ факультету Київський наиіональний університет \\ імені Тараса Шевченка \\ м. Київ, Украӥна
}

Авторська заувага: пропоновані висновки $є$ результатом викладання філософії впродовж 3-х семестрів (II семестру 2019-20 н. р.; I та II семестрів 2020-21 н. p.) 3 практикуванням різних форматів завдань (усних, письмових, змішаних) та форм контролю їх виконання (від класичних до новітніх);

Терміноуточнювальна заувага: 1) освітньо-навчальне інтеракиіювання (тут: навчальна співпраця викладача та студентів; інакше: різнорівнева співпраця керівництва вишу, факультету/інституту, викладачів, студентів та роботодавців); 2) навчальна співпрачя (комунікація поміж викладачем та студентами в межах аудиторних занять, консультативні заняття-за-запитом, керівництво науковими дослідженнями тощо); 3) теорезис (теоретична та теорійна частина навчальної дисципліни); 4) праксис (завдання-на-виконання для студентів задля знаннєздобування, випрацьовування та/або закріплювання їх навичокумінь); 5) лектор (транслювальник теорезису та (спів)розробляльник праксису); 6) семінарувальник (керівник та/або модерувальник семінару, або його учасник); 7) семінарування (загалом: проведення/ модерування та/або участь у семінарському занятті; для студентів: комплекс $\{\mathrm{a}\}$ пресемінарування, тобто самопідготовки до семінарського заняття, $\{\mathrm{b}\}$ активної участі впродовж семінарського заняття, $\{c\}$ постсемінарування, тобто доопрацьовування матеріалів щодо навчальних лакун, донотовування виниклих ідей щодо питань теми та/або відпрацьовування заняття через виконання відповідних завдань теми; для викладачів: комплекс \{a\} пресемінарування, тобто сценаріювання майбутнього заняття, $\{b\}$ модерування семінарського заняття; \{c\} постсемінарування, тобто заповнювання навчальної документації; перевіряння виконаних відпрацьовувальних завдань, їх оцінювання та коментування; коригування навчальних завдань з наступних тем тощо); 8) навчальна лакуна (для студента: дещо невідоме або недостатньо 
роз'яснене, що потребує додаткового опрацювання навчальних матеріалів; для викладача: дещо невідоме, що потребує додаткового опрацювання дослідницьких матеріалів); 9) сценаріювання семінарського заняття (виокремлення викладачем питань теми для розгляду впродовж семінарського заняття; створення алгоритмів розгляду питань теми; роз'яснення вимог виконання кожного завдання теми; підготовка роздаткових тематичних матеріалів та шаблонів); 10) навчальна документація (журнал успішності та персональні кабінети студентів: внесення отриманих балів за виконані завдання; журнал відвідувань та виконань: позначання призначеного та виконаного; заповнювання внутрішніх/кафедральних та зовнішніх/факультетських-й-інститутських звітів тощо); 11) оптимізування опанування навчальної дисципліни (коригування навчальних матеріалів - переважно завдань - залежно від швидкості-та-якості засвоюваності й розуміння, тобто вміння пояснити сутність, студентами); 12) індивідуальне рейтингування студентів (визначання викладачем лектором-та-семінарувальником що саме студенту/студентці необхідно посилити i y який спосіб для оптимального опанування навчальної дисципліни з індивідуальними зисками для нього/неї як майбутнього фахівця); 13) технічне оиінювання (виявляння засвоєного студентом та результування цього у балах без опікування що саме слід коригувати у його/ії опануванні навчальної дисципліни для індивідуального зростання як майбутнього фахівця); 14) навчальне налаштування (психічний стан студента/студентки, яким окреслена відкритість та готовність семінарувати).

Упродовж «ковідного періоду» (3 12 березня 2020 й донині) викладання навчальних дисциплін у вишах було переформатоване: 3 офлайн-занять (аудиторних) на переважно онлайн-заняття. Викладачі та студенти отримали досвід зміни способу освітньо-навчального інтеракціювання без втрат «доставляння навчального матеріалу». Переваги онлайн-занять: 1) економія часу на дорогу до вишу і назад; 2) умовно-комфортне середовище навчання (тільки для студентів 3 окремою кімнатою/квартирою); 3) власний темп навчання (індивідуально); 4) можливість отримати консультацію викладача без «сторонніх очей-вух»; 5) опанування нових технологій (девайсоможливості та програмне забезпечення) і технік-прийомів (навчання й самонавчання) тощо. Недоліки онлайн-занять: 1) »черга» на виступ та/або презентування власних відповідей (за умови чисельності груп від 20 до 30 студентів); 2) нестабільна робота мережі та/або відсутність інтернету (спорадично); 3) співмешканці (щодо студентів з гуртожитків та/або родин 3 декількома учнями/студентами); 4) індивідуальна робота щодо виконання навчальних завдань (через упереджання 140 
захворювання; різну місцевість; техніко-технологічні труднощі тощо); 5) збіг «робочого» та «навчального» графіків (для тих, хто працює за фахом) тощо.

Завдання викладача полягає в оптимізуванні навчального процесу задля успішного опанування окремої навчальної дисципліни усіма студентами. Роль семінарувальника (тут: керівника семінару) має розширитися до «непомітного модерувальника» (тільки спрямовує розгляд теми/питання короткими коментуваннями, тезами або запитаннями), проте роль лектора не виключена. Лектор упродовж семінарського заняття «реєструє» засвоюваність навчального матеріалу, презентованого ним на лекційному занятті та доопрацьованого кожним студентом/студенткою протягом пресемінарування задля подальшого оптимізування опанування навчальної дисципліни. Зауважу, що «реєстрування засвоюваності навчального матеріалу» та «індивідуальне рейтингування студентів» викладачем може здійснюватися тільки за умови: він постає і лектором, і семінарувальником; за практикованого нині у виш-викладанні розмежування лектора (антропоодиниця-1) та семінарувальника (антропоодиниця-2) «діяльність» викладача зведена до «технічного оцінювання засвоєного», але не до «індивідуальних змін кожного студента».

Виш-освіта та виш-навчання сьогодні студентоцентровані й прагматизовані: «я витрачаю - час і кошти - та маю намір отримати максимум 3 можливого» (налаштування студентів); «я витрачаю час i власні ресурси задля формування нових поколінь та інакшого - ліпшого для мене і всього людства: безпечного, комфортного, ціннісного тощо - майбутнього» (налаштування викладачки філософії). Семінарування здійснюється завжди (здебільшого) 3 попередньою підготовкою: для сучасних студентів важливо не тільки отримати високу оцінку за виконані завдання (що раціонально зрозуміло), але й сформувати враження про себе в очах викладача (але не це головне) i - найголовніше - навчитися новому. Більшості життєвонеобхідно бути помітним та запам'ятатися викладачу, тому вони очікують зворотного зв'язку (хоча б мінімального коментування їх дій) та щиро радіють «вербальній підтримці» (конкретному хвалінню, або аргументованим запереченням їх «непомилковості» й/або «висловлених недостатньо інтелектуальних тез»). Викладач має помічати що саме, коли і 3 ким «іде» не так: кого треба - іноді - трохи перехвалити, аби надихнути, а кого варто трохи докорити, аби «тримався навчальних та етичних берегів».

Семінарування варто не «утримувати» в одному-єдиному форматі: це призвичаює студентів та уможливлює «шаблонізоване навчання». 
Формати семінарування відрізняються: 1) за характером активної роботи учасників (усно, письмово, змішано - усно-письмово та/або письмово-усно); 2) за формами контролю (класичними: доповідь, доповнення, дискусія, реферат, самостійна робота, контрольна робота; новітніми: індивідуальна тематична відповідь, тематичний розбір питання \{індивідуальний, командний, спонтаннокомандний, синхронізованокомандний $\}$, презентація та iі обговорення, реферування авторського тексту, есея, розтлумачення тези/вислову, самостійна робота 3 відкритими питаннями \{з умовами та без\}, контрольна робота 3 відкритими питаннями, тестування з закритими питаннями, експериментування \{кіновечір, ситуаційне моделювання\}, практикум \{текстовий, інтерактивний, тематичний експеримент, «хмара понять», «система категорій», «молодіжний сленг», «уроки минулого»\}, колективний проект \{з умовами $\}$, чат-дискусія, чат-опитування, jamboardзавдання тощо); 3) за типами завдань (відритого/закритого типу; спонтанні/попередньопідготовані; дефініціювальні, порівняльні, аналітичні, творчі, дослідницькі тощо); 4) за доступом інших студентів групи/потоку до індивідуальних розробок колег-студентів (індивідуальний або колективний; повністю відкритий; частково відкритий, тобто $\{$ a $\}$ можна слухати, робити нотатки, фотоекранувати, записувати відео виключно задля персонального подальшого використання, $\{b\}$ доступ для ознайомлення 3 матеріалами мають усі учасники, проте ім заборонено вносити правки, але вони можуть коментувати та/або оцінювати; повністю закритий) та ін.

На перших темах навчальної дисципліни семінарування має формуватися з найпростіших та середньоскладних завдань, прикладами яких є: 1) питаннєві («сформулюйте запитання...»); 2) думкоформувальні («яка Ваша думка щодо...»); 3) дефініціювальні («запропонуйте власне визначення...»); 4) виокремлювальні («з-поміж запропонованих понять, виокремте...») 5) порівняльні («співставте ... та виокремте спільне/відмінне») тощо. За допомогою зазначених завдань студенти «призвичаюються» до специфіки навчальної дисципліни, «схоплюють» iii сутність, налагоджують параметри освітньо-навчального інтеракціювання тощо. Щонаступної теми варто ускладнювати завдання, але не оминати увагою найпростіші та середньоскладні, оскільки саме вони постають основою для «подолання» складних (аналітико-творчих) та надскладних (дослідницьких) завдань.

Постає закономірне запитання «Яким чином змусити студентів виконувати завдання?». По-перше, змусити людину дещо виконувати нерезультативно - виконання буде зафіксовано, але компетенції можуть не сформуватися і у досвіді студента/студентки зміни будуть 142 
начерковими. По-друге, щоб студенти виконували навчальні завдання необхідно: 1) вміти чути «замовника освітніх послуг» (студенти теж мають право голосу); 2) запитувати прямо - які завдання їм би хотілося виконувати (що далі векторує дії викладача для «оформлення» навчального завдання у будь-який «прийнятний для усіх формат»); 3) пропонувати «завданнєвий вибір», тобто розробляти більше різноманітних тематичних завдань (по-перше, кожен студент усвідомлює об'єктивно свій рівень і цілком спроможний виокремити оптимальні для виконання завдання; по-друге, за світоглядними орієнтирами конкретних студентів деякі завдання $є$ неприйнятними для виконання; по-третє, відсутність «навчального налаштування» теж необхідно враховувати). Сам викладач має переорієнтуватися від наразі нерезультативної формули «Я усе сам зроблю, оскільки краще знаю!» до співпрацювальної формули - «Знаю, вмію, розумію, але краще поспостерігаю та запитаю щодо можливих змін». Відповідно, сучасний викладач філософії постає (спів)розробляльником праксису: він створює навчальну основу, але радо вносить коригування задля спільнвигодового майбутнього.

Отже, філософія не є навчальною дисципліною для «ознаннєвлювання», «навичкоформування» та «вміннєвдосконалювання» студентів вишу, вона уможливлює свідоме саморозвивання кожного задля індивідуальних та суспільних зисків усього людства, а оптимізоване семінарування може цьому посприяти.

DOI https://doi.org/10.30525/978-9934-26-114-5-36

\title{
MODERN PHILOSOPHY OF INCLUSIVE EDUCATION OF DEAF STUDENTS
}

\author{
Zamsha A. V. \\ PhD in Psychology, \\ Head of Sign Language Education Division \\ Mykola Yarmachenko Institute of Special Education and Psychology \\ of the NAES of Ukraine \\ Kyiv, Ukraine
}

The practice of implementation of inclusive philosophy in deaf education raises two important issues - the academic integration and the social integration of such children in the general education settings. 